\title{
PENGEMBANGAN MEDIA PEMBELAJARAN BERBANTUAN KOMPUTER UNTUK MENANAMKAN KESADARAN LINGKUNGAN BAGI SISWA SMP
}

\author{
Lusty Firmantika, Mukminan \\ Program Studi IPS PPs UNY, Universitas Negeri Yogyakarta \\ Lusty_firmantika@yahoo.co.id,dr_mukminan@yahoo.com
}

\begin{abstract}
Abstrak
Tujuan penelitian ini adalah: (1) menghasilkan media pembelajaran berbantuan komputer untuk menanamkan kesadaran lingkungan; (2) mengetahui kelayakan produk media pembelajaran; (3) mengetahui tingkat kesadaran lingkungan. Penelitian ini menggunakan metode penelitian dan pengembangan. Data penelitian ini dikumpulkan melalui lembar validasi dan angket kesadaran lingkungan. Selanjutnya data dianalisis menggunakan statistik deskriptif dan hasilnya dinyatakan dalam skala 1-100. Hasil penelitian menunjukkan bahwa: (1) media pembelajaran berbantuan komputer dikembangkan melalui enam langkah yaitu identifikasi tujuan pembelajaran, analisis kebutuhan, desain pengembangan, produk awal, validasi/evaluasi, dan produk akhir; (2) media pembelajaran berbantuan komputer dinilai layak berdasarkan hasil validasi ahli materi, ahli media, one to one evaluation, small grop evaluation, dan field trial; (3) hasil angket pada field trial menunjukkan bahwa tingkat kesadaran lingkungan siswa cukup tinggi.
\end{abstract}

Kata Kunci: media pembelajaran berbantuan komputer, kesadaran lingkungan

\section{DEVELOPING COMPUTER ASSISTED INSTRUCTIONAL MEDIA FOR INCULCATING ENVIRONMENTAL AWARENESS IN JUNIOR HIGH SCHOOL STUDENTS}

\author{
Lusty Firmantika, Mukminan \\ Program Studi IPS PPs UNY, Universitas Negeri Yogyakarta \\ Lusty_firmantika@yahoo.co.id,dr_mukminan@yahoo.com
}

\begin{abstract}
This research aims to: (1) develop computer-assisted instructional media to inculcate environmental awareness; (2) reveal the appropriateness of the developed instructional media product; (3) reveal the level of environmental awareness. The data were collected through a validation sheet and a student questionnaire of environmental awareness. Then the data were analyzed using the descriptive statistics and the result was represented by scale of 1-100. The results of the study are as follows. (1) The computerassisted instructional media were developed through six steps consisted identification of instructional goals, needs analysis, development design, preliminary product, validation/evaluation, and final product. (2) The computer-assisted instructional media are considered appropriate based on the results of the subject-matter expert's validation, media expert, one-to-one evaluation, small group evaluation, and field trials. (3) The results of the field trial questionnaire show that the level of environmental awareness of the students is high.
\end{abstract}

Keywords: computer-assisted instructional media, environmental awareness 


\section{Pendahuluan}

Pembelajaran Ilmu Pengetahuan Sosial (IPS) diperlukan dalam kehidupan sebab dapat mengarahkan siswa menjadi warga negara yang demokratis, bertanggung jawab, dan cinta damai (Standar Isi untuk Satuan Pendidikan Dasar dan Menengah, 2006, p.159).

Keberhasilan pembelajaran IPS dapat ditunjukkan dengan tingkat ketercapaian tujuan pembelajaran. Berapa persen tujuannya tercapai. Tujuan pembelajaran itu dapat tercapai jika didukung oleh fasilitas belajar yang baik. Fasilitas belajar meliputi materi, media, sarana prasarana, lingkungan. Fasilitas yang lengkap juga kurang berpengaruh baik jika kegiatan belajar mengajar kurang menarik.

Guru IPS juga harus menggunakan metode yang tepat, meliputi aspek yang luas, mengajarkan kondisi nyata dalam kehidupan, mengajarkan nilai-nilai kehidupan, mengajarkan berpikir kritis, kreatif, dan inovatif. Pembelajaran IPS juga diharapkan selalu mengikuti perkembangan masyarakat yang selalu dinamis.

Pembelajaran Ilmu Pengetahuan Sosial (IPS) sesuai perkembangan masyarakat jika mengangkat tema-tema yang sedang terjadi (current events). Tema-tema kontekstual yang terjadi dalam masyarakat akan membantu siswa untuk lebih memahami materi yang disampaikan karena siswa dapat menghayati bahkan mengalami sendiri. Pembelajaran yang kurang menarik menyebabkan motivasi belajar siswa rendah.

Motivasi belajar yang rendah sangat berpengaruh pada hasil belajar siswa. Jika siswa merasa nyaman dalam pembelajaran hasilnya akan maksimal, tetapi jika kurang senang maka akan minimal. Siswa merasa belajar IPS tidak penting sehingga saat pelajaran berlangsung cenderung ramai sendiri. Siswa juga cepat merasa bosan. Materi pelajaran yang disampaikan oleh guru kurang mengena pada siswa. Akibatnya hasil belajarnya kurang baik, tercermin dari nilai yang diperoleh kurang maksimal.

Salah satu upaya untuk menarik perhatian siswa yaitu dengan menggunakan media pembelajaran. Gagne dan Briggs (Arsyad, 2009, pp.4-5) menyatakan bahwa media pembelajaran yang digunakan dapat berupa media cetak dan media elektronik seperti buku, tape, kaset, video kamera, video recorder, film, slide, foto, gambar, grafik, televisi dan komputer. Pengembangan media pembelajaran juga sangat dipengaruhi oleh tingkat penguasaan teknologi komputer. Pada kenyataannya banyak guru yang kurang menguasai teknologi, khususnya pembuatan media pembelajaran berbantuan komputer. Masalah tersebut mengakibatkan banyak sekolah yang memiliki fasilitas komputer yang lengkap tetapi tidak tersedia Sumber Daya Manusia (SDM) yang mampu menggunakannya secara optimal. Fasilitas komputer hanya dijadikan sebagai pajangan dan tidak memberikan kontribusi yang berarti terhadap pembelajaran.

Permasalahan pembelajaran IPS bukan hanya seperti yang telah diuraikan, tetapi juga memiliki masalah yang lain. Masalahnya yaitu materi pelajaran yang luas tetapi alokasi waktunya kurang. Hal itu menyebabkan tidak semua materi pelajaran dapat disampaikan dengan baik oleh guru. Seperti yang terjadi dalam Standar Kompetensi (SK) memahami lingkungan kehidupan manusia, dan memahami usaha manusia untuk mengenali perkembangannya. Materi ajar yang disampaikan kepada siswa kurang membahas tentang kerusakan lingkungan, dampak dan solusi untuk mengatasinya. Seharusnya materi dapat tersampaikan dengan baik kepada siswa, mengingat kerusakan lingkungan masalah lingkungan sudah menjadi masalah global yang memerlukan penanganan khusus. Selain itu Indonesia merupakan daerah ring of fire sehingga rawan bencana alam seperti gempa bumi dan tsunami. Pengetahuan yang minim tentang bagaimana memahami bencana dapat menimbulkan kerusakan yang semakin parah. Jika siswa telah dibekali pengetahuan yang baik tentang kerusakan lingkungan, penyebab, dampak, serta solusinya, maka diharapkan dapat mengurani risiko terhadap bencana. Materi ajar diberikan secara interaktif dan menarik sehingga siswa akan merasa rugi jika tidak mempelajarinya.

Perkembangan ilmu dan teknologi membantu manusia dalam berbagai kepentingan, seperti mengembangkan media pembelajaran. Bagi seorang guru media pembelajaran merupakan kebutuhan primer. Media pembelajaran dapat dibuat sangat menarik dengan menggunakan bantuan komputer. Media tersebut dikembangkan sesuai dengan kondisi nyata masyarakat. 
Apabila media berbantuan komputer diterapkan dalam pembelajaran IPS, maka diharapkan akan meningkatkan minat belajar siswa sehingga hasil belajarnyapun dapat maksimal.

Pada intinya, pengembangan media pembelajaran dalam IPS sangat penting agar Kegiatan Belajar Mengajar (KBM) lebih menarik dan kontekstual (sesuai kondisi nyata) sehingga meningkatkan perhatian siswa. Jika perhatian siswa meningkat, hasil belajarnya juga diharapkan menjadi lebih baik.

\section{Pembelajaran IPS}

Definisi pembelajaran IPS dikemukakan oleh beberapa ahli, salah satunya National Council for the Social Studies (NCSS). NCSS mendefinisikan bahwa IPS adalah: the integrated study of social sciencies and humanities to promote civic competence. Within the school program, social studies provides coordinated, systematic study drawing upon such disciplines as anthropology, archaeology, ecomomics, geography, history, law, philosophy, political science, psychology, religion, and sociology, as well as appropriate content from the humanities, mathematics, and natural sciences (Ellis, 1998, p.2).

Ilmu Pengetahuan Sosial (IPS) juga merupakan seleksi dari disiplin ilmu-ilmu sosial dan humaniora serta kegiatan dasar manusia yang diorganisasikan dan disajikan secara ilmiah dan psikologis untuk tujuan pendidikan (Soematri, 2001, p.92). IPS merupakan bidang studi yang mempelajari, menelaah, menganalisa gejala dan masalah sosial di masyarakat dengan meninjau berbagai aspek kehidupan atau satu perpaduan, maka pembelajaran IPS dapat diartikan sebagai perangkat peristiwa yang dilakukan guru untuk mengarahkan anak didik dalam memahami mengenai berbagai fenomena sosial yang terjadi di masyarakat. Oleh karena itu, penjabaran konsepkonsep, pokok bahasan dan sub pokok bahasan IPS harus disesuaikan dengan tingkat pengetahuan, pemahaman, dan kemampuan analisis siswa terhadap kondisi sosial masyarakat.

Sementara itu, tujuan dari pembelajaran IPS pada dasarnya untuk mempersiapkan para peserta didik sebagai warga negara yang menguasai pengetahuan (knowledge), ketrampilan (skill), sikap dan nilai (attitudes dan values) yang dapat digunakan sebagai kemampuan untuk memecahkan masalah pribadi atau masalah sosial, serta kemampuan mengambil keputusan dan berpartisipasi dalam berbagai kegiatan kemasyarakatan agar menjadi warga negara yang baik (Sapriya, 2009, p.12).

Melihat ruang lingkup mata pelajaran IPS d iatas, jika pembelajaran IPS diajarkan dan dipelajari secara terarah dan baik, dapat membina anak didik berpikir integratif untuk dirinya sendiri dan untuk kepentingan kehidupan pada umumnya. Pendidikan IPS dapat dijadikan salah satu sarana untuk menjadikan manusia berkarakter yang baik dengan cara membekali peserta didik dengan pengetahuan yang berguna, mengembangkan saling pengertian yang lebih baik, sehingga dapat memberikan sumbangan terhadap pendidikan umum. Oleh karena itu, agar pembelajaran IPS dapat terlaksana dengan baik diperlukan lingkungan belajar yang menyenangkan dan kondusif. Lingkungan belajar yang menyenangkan dapat diciptakan dari penggunaan media pembelajaran yang menarik dan sesuai perkembangan masyarakat seperti media pembelajaran berbantuan komputer.

\section{Media Pembelajaran Berbantuan Komputer}

Menurut Heinich (1993, p.5) dalam Newby menyatakan bahwa: "instructional media are a means by which information can be delivered to a learner. In one case the selected may be audiotape, in still another it may be computer software. Each medium represents a means of connecting leaners, the teacher, and the instruction (Newby, 2000, p.16). Pernyataan tersebut menunjukkan bahwa media pembelajaran merupakan perantara yang dapat menyampaikan informasi kepada siswa. Media tersebut dapat berupa rekaman, perangkat lunak komputer, atau lainnya yang membantu pembelajaran.

Sudjana \& Rivai (2007, pp.137-138) memaparkan bahwa pemberdayaan komputer dalam pembelajaran memiliki beberapa keuntungan diantaranya: (1) cara kerja baru dengan komputer akan membangkitkan motivasi siswa dalam belajar; (2) warna, musik dan grafis animasi dapat menambahkan kesan realisme pada siswa; (3) respon pribadi yang cepat dalam kegiatan-kegiatan belajar siswa akan menghasilkan penguatan yang tinggi; (4) kemampuan memori memungkinkan penampilan siswa yang telah lampau 
direkam dan dipakai dalam merencanakan langkah-langkah selanjutnya dikemudian hari; (5) kemampuan daya rekam komputer memudahkan dalam pengajaran individual bagi semua taraf intelektual siswa.

Salah satu media pembelajaran berbantuan komputer yang dapat digunakan berupa CD pembelajaran. CD pembelajaran merupakan salah satu alat bantu pembelajaran memiliki peranan yang sangat membantu dalam menjelaskan hal-hal abstrak menjadi jelas dan sederhana serta lebih efisien dalam waktu. CD pembelajaran ini diharapkan dapat meningkatkan kualitas pembelajaran melalui inovasi dan penerapan teknologi informasi. Sehingga CD interaktif ini akan menjadi mitra dan penyedia solusi teknologi pembelajaran dan pelatihan berbantuan komputer.

Media pembelajaran yang dikembangkan harus memiliki kualitas yang baik, kreatifitas yang tinggi, evaluasi dan revisi yang tepat. Hal ini sesuai dengan pendapat "high quality and creative instructional design coupled with careful evaluation and revision are also necessary" (Alessi \& Trollip, 2001, pp.5-6).

\section{Kriteria Kelayakan Media}

Produk media pembelajaran yang digunakan harus memiliki kualitas yang baik. Suatu media pembelajaran dikatakan baik jika memenuhi kriteria tertentu. Menurut Walker \& Hess dalam Arsyad, (2009, pp.175-176) mengatakan bahwa untuk mengetahui kualitas media dalam pembelajaran harus melihat kriteria sebagai berikut. (1) Kualitas isi dan tujuan yang meliputi ketepatan, kepentingan atau manfaat yang dapat diperoleh, kelengkapan, keseimbangan, daya tarik, kewajaran, dan kesesuaian dengan situasi siswa. (2) Kualitas instruksional yang memberikan kesempatan belajar, memberikan bantuan untuk belajar, kualitas motivasi, fleksibilitas instruksionalnya, hubungan dengan program pengajaran lainnya, kualitas tes dan penilaiannya, dapat memberikan dampak bagi guru dan siswa. (3) Kualitas teknis yang meliputi: keterbacaan, kemudahan menggunakan, kualitas tampilan/tayangan, kualitas penanganan respon siswa, kualitas pengelolaan programnya, dan kualitas pendokumentasiannya.

Thorn dalam Munir (2009, p.219), menyatakan bahwa ada beberapa kriteria untuk menilai media interaktif yaitu: (1) kemudahan navigasi; (2) kandungan kognisi; (3) presentasi informasi yang digunakan untuk menilai isi dan program pengembangan media; (4) integrasi media; (5) artistika dan estetika; (6) fungsi secara keseluruhan. Kriteria tersebut menunjukkan bahwa suatu media yang baik jika dirancang sesederhana mungkin sehingga pengguna tidak memelukan pengetahuan kompleks tentang media; memiliki pengetahuan dan informasi yang jelas dan dapat dipertanggungjawabkan secara ilmiah; dapat diintegrasikan dalam pembelajaran; menarik sehingga dapat memberikan motivasi siswa untuk belajar; sesuai dengan karakteristik siswa.

Menurut Chee \& Wong (2003, pp.136-140) kualitas media pembelajaran dapat ditinjau dari tiga hal yaitu: (1) appropriateness; (2) accuracy, currency, and clarity; (3) screen presentation and design: text, graphics, color, animation, audio, video clip.

Berdasarkan penjelasan beberapa teori tentang kriteria kualitas media yang telah diuraikan, diketahui bahwa kualitas media pembelajaran, dapat dilihat dari tiga aspek. Aspek tersebut meliputi aspek pembelajaran, aspek isi/materi, dan aspek media (tampilan dan pemrograman).

Kelayakan pada aspek pembelajaran menunjukkan bahwa penggunaan media menjadikan proses pembelajaran menjadi efisien dan efektif. Pada aspek isi atau materi menunjukkan bahwa dengan menggunakan media, materi pelajaran menjadi lebih mudah dan jelas dipahami siswa. Pada aspek media (tampilan dan pemrograman) menunjukkan bahwa dengan menggunakan media, dapat memperlancar proses penyampaian informasi karena dikemas secara lebih menarik dan up-to-date. Ketiga aspek saling dukung satu sama lain dan menjadi satu kesatuan utuh yang menjadikan media pembelajaran dinilai layak digunakan seperti dalam penelitian ini,

Media pembelajaran berbantuan komputer dalam penelitian ini memiliki tujuan untuk menanamkan kesadaran lingkungan bagi siswa SMP.

Kesadaran Lingkungan

Kesadaran lingkungan dapat dibangun melalui proses pendidikan. Kesadaran itu ada selama dalam diri manusia mengalir daya-daya yang menjelmakan pikiran yang berkembang 
sesuai tingkat kematangan manusia dan berpengaruh terhadap lingkungannya. Penanaman kesadaran lingkungan lebih efektif jika tidak hanya bersifat teoretis, tetapi langsung praktik secara nyata (Suryadipura, 2002, p.63). Neolaka (2008, p.34), menyatakan bahwa kesadaran lingkungan semakin penting dimiliki setiap orang karena manusia hidup dari lingkungan dan jika lingkungan rusak maka manusia juga yang celaka. Chiras (1988, pp.441-442) menyatakan bahwa dasar kesadaran lingkungan adalah etika lingkungan (enviromental ethics are the foundation of a sustainable society). Sustainable ethics have three strategies of new resorce-consumption. The first strategy is conservation, curtailing excessive resources use. The second is reuse and recycling of all materials. The third is the use of more renewable resouces and fewer nonrenewable resouces. The fourth and most important is the control of population growth.

Menurut Neolaka (2008, pp.41-65) kesadaran lingkungan dipengaruhi oleh faktor-faktor seperti pengetahuan, kemiskinan (kesejahteraan hidup), kemanusiaan dan gaya hidup. Faktorfaktor tersebut juga berpengaruh terhadap kesadaran lingkungan yang dimiliki siswa SMP yang dijadikan sebagai subjek coba penelitian.

Siswa SMP termasuk dalam kategori remaja karena berada dalam peralihan antara masa anakanak ke dewasa. Oleh karena itu perkembangan remaja dalam kehidupan perlu mendapat perhatian khusus. Remaja tingkat emosinya masih labil, penuh rasa ingin tahu, dan berusaha mencari identitas diri. Pendidikan yang tepat merupakan cara mengontrol perkembangan remaja, terutama aspek kognitifnya.

Perkembangan kognitif merupakan proses memperoleh, menyusun dan menggunakan pengetahuan serta kegiatan mental seperti berpikir, menimbang, mengamati, mengingat, menganalisis, mengevaluasi dan memecahkan masalah kehidupan melalui interaksi dengan lingkungan (Ali, 2008, p.26).

Menurut Piaget perkembangan kognitifnya pada masa remaja sudah mencapai tahap operasi formal (operasi kegiatan-kegiatan mental tentang berbagai gagasan). Remaja, secara mental telah dapat berpikir logis tentang berbagai gagasan yang abstrak (Yusuf, 2004, p.195).
Perkembangan intelektual remaja termasuk di dalamnya perkembangan kognitif dipengaruhi oleh faktor hereditas dan lingkungan baik keluarga, sekolah maupun masyarakat (Ali, 2008, p.34). Oleh karena itu, agar perkembangan kognitif berjalan baik maka perlu diciptakan lingkungan belajar yang kondusif baik di rumah maupun sekolah. Proses pembelajaran menjadi lebih menyenangkan. Hasil belajar yang diperoleh juga akan maksimal.

Menurut Bruner dalam (Poerwanti \& Widodo, 2002, p.124) menyatakan bahwa siswa dalam tahap remaja akan lebih senang belajar dengan menggunakan bentuk-bentuk simbol dengan cara yang semakin abstrak. Guru dapat membantu remaja untuk melakukan hal ini dengan selalu menggunakan keterampilan proses dalam pembelajaran dan dengan memberi penekanan pada penguasaan konsep.

Yusuf (2002, p.196) menyatakan bahwa implikasi pendidikan dari periode berpikir operasi formal adalah perlunya dipersiapkan program pendidikan yang dapat memfasilitasi perkembangan kemampuan berpikir siswa (remaja). Upaya yang dapat dilakukan seperti: (1) penggunaan metode mengajar yang mendorong anak untuk aktif bertanya, mengemukakan gagasan atau mengujicobakan suatu materi; (2) melakukan dialog, diskusi atau curah pendapat (brain storming) dengan siswa tentang berbagai masalahmasalah sosial atau berbagai aspek kehidupan.

Berdasarkan berbagai pendapat di atas, maka perlu dikembangkan pembelajaran yang tepat dan sesuai dengan perkembangan remaja untuk meningkatkan kemampuan kognitif, melatih keterampilan (psikomotorik) dan tetap memperhatikan nilai nilai serta norma-norma yang ada. Oleh karena itu, diperlukan alat bantu yang dapat dijadikan sebagai perantara dalam pembelajaran agar menjadi lebih efisien, efektif, interaktif dan atraktif. Media berbantuan komputer menjadi salah satu solusinya.

Ada beberapa masalah yang menjadi fokus kajian dari jurnal ini antara lain: Bagaimana pengembangan media pembelajaran berbantuan komputer yang digunakan untuk menanamkan kesadaran lingkungan bagi siswa SMP?; Bagaimana kelayakan media pembelajaran?; Bagaimana tingkat kesadaran lingkungan siswa? 


\section{Metode Penelitian}

Penelitian ini menggunakan metode penelitian dan pengembangan (reearch and development) yang mempunyai tujuan mengembangkan media pembelajaran mata pelajaran IPS.

Produk yang dikembangkan berupa software media pembelajaran dalam bentuk Compact Disc (CD) untuk IPS SMP materi kerusakan lingkungan, penyebab, dampak, solusi dan evaluasi yang sesuai dan layak sebagai sumber belajar.

Langkah-langkah pengembangan atau prosedur pengembangan dari model pengembangan Dick \& Carey (2005, pp.6-8), Borg \& Gall (2007, pp.589-592) adalah sebagai berikut: (1) identifikasi tujuan pembelajaran, (2) analisis kebutuhan, (3) desain pengembangan, (4) produk awal, (5) evaluasi, (6) produk akhir.

Proses validasi dalam penelitian ini meliputi: (1) validasi ahli, (2) one-to-one evaluation, (3) small group evaluation, 4) field trial. Aspek yang divalidasi mencakup pembelajaran, isi, tampilan, dan pemrograman produk yang dikembangkan.
Subjek ujicoba atau responden yang terlibat dalam penelitian ini adalah siswa kelas VII SMPN 1 Bantul, SMPN 1 Pleret dan SMPN 1 Bambanglipuro.

Data hasil penelitian ini adalah berupa tanggapan ahli materi, ahli media dan siswa terhadap kelayakan produk yang telah dikembangkan ditinjau dari aspek materi dan aspek media. Data berupa komentar, saran perbaikan dan hasil pengamatan peneliti selama proses ujicoba dianalisis secara deskriptif dan disimpulkan sebagai masukan untuk memperbaiki atau merevisi produk yang telah dikembangkan. Sementara tanggapan ahli materi, ahli media dan siswa berupa data skor yang diperoleh melalui angket, dianalisis secara deskriptif kuantitatif dengan teknik persentase dan kategorisasi.

Data yang diperoleh dari angket siswa diubah menjadi data interval. Pedoman pengubahannya dengan menggunakan skoring yang dapat dilihat pada tabel sebagai berikut:

Tabel 1. Skoring Kriteria Kualitas Produk

\begin{tabular}{lcl}
\hline Kriteria & Skor & Makna \\
\hline Sangat Baik & 5 & $\begin{array}{l}100 \% \text { sesuai dengan unsur-unsur yang ada dalam pertanyaan/pernyataan } \\
\text { tersebut. }\end{array}$ \\
Baik & 4 & $\begin{array}{l}80 \% \text { sesuai dengan unsur-unsur yang ada dalam pertanyaan/pernyataan } \\
\text { tersebut. }\end{array}$ \\
Cukup & 3 & $\begin{array}{l}60 \% \text { sesuai dengan unsur-unsur yang ada dalam pertanyaan/pernyataan } \\
\text { tersebut. } \\
\text { Kurang }\end{array}$ \\
Sangat Kurang & 2 & $\begin{array}{l}40 \% \text { sesuai dengan unsur-unsur yang ada dalam pertanyaan/pernyataan } \\
\text { tersebut. } \\
20 \% \text { sesuai dengan unsur-unsur yang ada dalam pertanyaan/pernyataan } \\
\text { tersebut. }\end{array}$
\end{tabular}

Pada angket terdapat lima pilihan jawaban yang dapat diberikan oleh siswa sebagai tanggapan tentang produk yang dikembangkan. Lima pilihan jawaban tersebut yaitu sangat baik (5), baik (4), cukup (3), kurang (2), dan sangat kurang (1). Seandainya tanggapan siswa "sangat baik" pada suatu butir pertanyaan-pernyataan, maka skor butir tersebut sebesar "5", demikian seterusnya.
Skor yang diperoleh kemudian dikonversikan menjadi data kuantitatif .Kelayakan media pembelajaran berbantuan komputer dari ahli materi dan media dinyatakan dengan angka berskala (1-5). Skor yang diperoleh kemudian dikonversikan menjadi data kualitatif skala lima (5), dengan menggunakan acuan rumus pendekatan Penilaian Acuan Patokan (PAP) sebagai berikut: Tabel 2. Penilaian Acuan Patokan (PAP) 


\begin{tabular}{|c|c|c|c|}
\hline Nilai & & Skor & \\
\hline A & $\overline{\mathrm{X}}_{\mathrm{i}}+1,80 \mathrm{SB}_{\mathrm{i}}$ & $<\mathrm{X}$ & \\
\hline B & $\overline{\mathrm{X}}_{\mathrm{i}}+0,60 \mathrm{SB}_{\mathrm{i}}$ & $<\mathrm{X} \leq$ & $\overline{\mathrm{X}}_{\mathrm{i}}+1,80 \mathrm{SB}_{\mathrm{i}}$ \\
\hline C & $\overline{\mathrm{X}}_{\mathrm{i}}-0,60 \mathrm{SB}_{\mathrm{i}}<\mathrm{X}$ & $<\mathrm{X} \leq$ & $\overline{\mathrm{X}}_{\mathrm{i}}+0,60 \mathrm{SB}_{\mathrm{i}}$ \\
\hline $\mathrm{D}$ & $\bar{X}_{\mathrm{i}}-1,80 \mathrm{SB}_{\mathrm{i}}<\mathrm{X}$ & $<x \leq$ & $\bar{X}_{i}-0,60 \mathrm{SB}_{\mathrm{i}}$ \\
\hline $\mathrm{E}$ & & $\mathrm{X} \leq$ & $\overline{\mathrm{X}}_{\mathrm{i}}-1,80 \mathrm{SB}_{\mathrm{i}}$ \\
\hline
\end{tabular}

(Sukardjo, 2006, p.52)

Pada tahap uji lapangan diperoleh juga data yang berasal dari angket kesadaran lingkungan. Angket tersebut memuat pernataan-pernyataan dari faktor pengetahuan, kesejahteraan hidup, kemanusiaan dan gaya hidup. Data yang diperoleh kemudian diskoring. Masing-masing faktor dicari skor secara keseluruhan. Setelah jawaban semua responden diskor, kemudian dicari ratarata ideal $\left(\mathrm{M}_{\mathrm{i}}\right)$ dan simpangan baku $\left(\mathrm{SD}_{\mathrm{i}}\right)$. Setelah itu, dapat diperoleh penentuan kriteria kesadaran lingkungan yaitu sebagai berikut:

Tabel 3. Penentuan Kriteria Kesadaran Lingkungan

\begin{tabular}{ccc}
\hline Interval & Skor & Kriteria \\
\hline $\mathrm{M}_{\mathrm{i}}+1,5 \mathrm{SD}_{\mathrm{i}}<\mathrm{X} \leq \mathrm{M}_{\mathrm{i}}+3 \mathrm{SD}_{\mathrm{i}}$ & $<\mathrm{X} \leq$ & Sangat Tinggi \\
$\mathrm{M}_{\mathrm{i}}+0,5 \mathrm{SD}_{\mathrm{i}}<\mathrm{X} \leq \mathrm{M}_{\mathrm{i}}+1,5 \mathrm{SD}_{\mathrm{i}}$ & $<\mathrm{X} \leq$ & Tinggi \\
$\mathrm{M}_{\mathrm{i}}+0,5 \mathrm{SD}_{\mathrm{i}}<\mathrm{X} \leq \mathrm{M}_{\mathrm{i}}+0,5 \mathrm{SD}_{\mathrm{i}}$ & $<\mathrm{X} \leq$ & Sedang \\
$\mathrm{M}_{\mathrm{i}}+1,5 \mathrm{SD}_{\mathrm{i}}<\mathrm{X} \leq \mathrm{M}_{\mathrm{i}}-0,5 \mathrm{SD}_{\mathrm{i}}$ & $<\mathrm{X} \leq$ & Rendah \\
$\mathrm{M}_{\mathrm{i}}+3 \mathrm{SD}_{\mathrm{i}}<\mathrm{X} \leq \mathrm{M}_{\mathrm{i}}-1,5 \mathrm{SD}_{\mathrm{i}}$ & $<\mathrm{X} \leq$ & Sangat Rendah \\
\hline
\end{tabular}

(Modifikasi Azwar, 2010, p.163)

Data yang diperoleh dalam skala 1 (satu) sampai 5 (lima) kemudian dikonversikan menjadi skala nilai 1 (satu) sampai dengan 100. Pedoman pengkonversiannya adalah sebagai berikut:

Tabel 4. Pedoman Penkonversian Skala 1-100

\begin{tabular}{ccc}
\hline Nilai & Rentang Skor & Kriteria \\
\hline A & $81-100$ & Sangat Baik \\
B & $61-80$ & Baik \\
C & $41-60$ & Cukup Baik \\
D & $21-40$ & Kurang Baik \\
E & $\leq 20$ & Sangat Kurang Baik \\
\hline
\end{tabular}

\section{Hasil Penelitian dan Pembahasan}

Hasil Pengembangan

Penelitian yang telah dilaksanakan merupakan jenis penelitian dan pengembangan. Produk yang dihasilkan berupa media pembelajaran berbantuan komputer untuk menanamkan kesadaran lingkungan bagi siswa SMP yang terintegrasi dalam mata pelajaran IPS yang dapat disimpan dalam bentuk Compact Disk (CD) dan softfile. Metode yang digunakan dalam pegembangan media pembelajaran berbantuan komputer diadaptasi dari model pengembangan Dick, W.
\& Carey, L. (2005, pp.6-8) dan Borg, W. R. \& Gall, M. D. (2007, pp. 589-592). Metode pengembangan tersebut dibagi menjadi enam tahap sebagai berikut: (1) identifikasi tujuan pembelajaran; (2) analisis kebutuhan; (3) desain pengembangan; (4) produk awal; (5) evaluasi; (6) produk akhir.

Hasil Uji Coba Produk

Penyajian dan Analisis Data Hasil Penilaian Ahli Materi

Data validasi dari ahli materi diperoleh dengan tiga cara, yaitu (a) menentukan penilaian dengan cara memberikan checklist pada angket validasi dan hasilnya menunjukkan aspek pembelajaran $(71,40)$ dan isi $(70)$ masuk ke dalam kriteria baik, (b) mendiskusikan materi bersama dengan peneliti, dan (c) memberikan catatan penting berkaitan dengan kebenaran materi serta pembetulan materi yang salah ataupun kurang lengkap.

Penyajian dan Analisis Data Hasil Penilaian Ahli Media

Data validasi ahli media diperoleh dengan cara memberikan kuesioner yang berisi tentang penilaian aspek pemrograman dan aspek 
tampilan, disertai dengan produk media yang dikembangkan kepada ahli media. Ahli media memeriksa dan mengamati aspek pemrograman dan aspek tampilan yang tersedia. Selain itu, ahli media memberikan komentar dan saran secara umum untuk memperbaiki media yang dikembangkan agar dapat digunakan pada tahapantahapan uji coba berikutnya. (a) Aspek tampilan termasuk dalam kategori baik karena memperoleh nilai 85,60. (b) Aspek pemrograman termasuk dalam kategori baik karena memiliki nilai 87,60 .

Hasil penilaian ahli materi dan media menunjukkan bahwa produk yang dikembangkan masuk dalam kategori baik. Oleh karena itu, media pembelajaran berbantuan komputer yang dikembangkan dinatakan sudah layak untuk diujicobakan ke lapangan dan melewati semua tahapan penelitian. Tahapan tersebut mulai dari one-to-one evaluation, small group evaluation dan field trial.

Penyajian dan Analisis Data dari Hasil Penilaian Uji Coba Siswa

\section{Deskripsi Data Hasil Penilaian One-to-One Evaluation}

Evaluasi tahap ini diperlukan untuk mendapatkan masukan tentang kelemahan-kelemahan atau kekurangan yang nyata terlihat ketika media digunakan oleh siswa. Uji coba dilakukan dengan cara masing-masing siswa menggunakan satu komputer untuk menampilkan produk media pembelajaran yang dikembangkan. Setiap siswa kemudian diberi lembar penilaian dan bertugas memberi tanggapan mengenai kualitas produk yang dikembangkan. Hasil penilaian pada tahap ini menunjukkan bahwa aspek tampilan $(89,60)$ dan aspek pemrograman (90) masuk ke dalam kriteria sangat baik.

\section{Deskripsi Data Hasil Penelitian Small Group Evaluation}

Setelah melalui tahap one-to-one evaluation dan merevisi produk yang dikembangkan berdasarkan saran dan komentar siswa, selanjutnya peneliti melakukan uji coba small group evaluation. Dalam uji coba ini siswa mengoperasikan komputer, kemudian mengamati produk multimedia yang dikembangkan dan memberikan penilaian terhadap kualitas media pembelajaran melalui lembar validasi yang sudah disediakan. Berdasarkan hasil penilaian small group evaluation yang dilakukan oleh aspek tampilan $(82,60)$ dan aspek pemrograman $(84,80)$ masuk ke dalam kategori sangat baik

\section{Deskripsi Data Hasil Penilaian Field Trial}

Uji coba lapangan (field trial) dilaksanakan di tiga sekolah. Pertama, dilaksanakan SMPN 1 Bambanglipuro; kedua, di SMPN 1 Bantul; ketiga, di SMPN 1 Pleret. Ketiga sekolah tersebut merupakan lembaga pendidikan formal yang terletak di Kabupaten Bantul. Kabupaten tersebut merupakan salah satu kabupaten yang rawan bencana alam seperti gempa, tsunami dan tanah longsor. Oleh karena itu, dengan adanya produk media pembelajaran diharapkan dapat membantu siswa menanamkan kesadaran lingkungan dan tanggap terhadap bencana sehingga kerusakan dapat diminimalisir.

Dalam uji coba lapangan, siswa mengoperasikan komputer, kemudian setiap siswa mengamati dan memberikan penilaian terhadap kualitas produk melalui lembar validasi yang sudah disediakan. Hasil penelitian pada tahap ini menunjukkan bahwa aspek tampilan $(81,13)$ dan aspek pemrograman $(84,07)$ masuk ke dalam kriteria sangat baik.

Deskripsi Data Hasil Angket Kesadaran Lingkungan

Hasil angket pada tahap uji coba lapangan (field trial) menunjukkan bahwa faktor pengetahuan $(79,93)$; faktor kesejahteraan hidup $(74,73)$; faktor kemanusiaan $(80,27)$ dan gaya hidup $(72,33)$ masuk ke dalam criteria baik. Hal ini menyatakan bahwa tingkat kesadaran lingkungan masyarakat yang diwakili siswa masuk dalam kategori tinggi. Namun, ada beberapa bagian aspek yang perlu ditambahkan dalam media dan ditekankan pada saat pembelajaran seperti: cara menebang pohon yang baik; pelaksanaan tindakan tanggap bencana; cara bijak dalam memanfaatkan sumber daya yang tersedia; penggunaan lampu LED, penggunaan tissue dan kertas; penggunaan air; penggunaan plastik; pengunaan shower sehingga media pembelajaran dapat berfungsi secara optimal. 


\section{Revisi Produk}

Produk media pembelajaran yang dikembangkan ini mendapat revisi di beberapa bagian. (1) Revisi ahli materi, ahli materi memberikan saran berupa penambahan jumlah gambar-gambar pada tampilan yang dapat mendukung materi pembelajaran agar lebih menarik dan mudah dipahami. (2) Revisi ahli media: jarak tombol next dan previous jangan terlalu jauh agar mudah digunakan, warna tombol lebih dipertajam, kecepatan animasi angin topan perlu ditambah, gambar-gambar korban jiwa dan depresi cukup diberikan ilustrasinya saja, musik pengiring lebih disesuaikan lagi. (3) Hasil uji coba siswa memberikan pendapat bahwa media pembelajaran berbantuan komputer untuk menanamkan kesadaran lingkungan bagi siswa SMP yang dikembangkan sudah tergolong baik. Namun, ada beberapa saran membangun yang dikemukakan siswa, seperti warna dibuat lebih colorfull agar lebih menarik. Selain itu, siswa juga berharap agar media dalam bentuk seperti ini dapat dikembangkan untuk materi lain bahkan mata pelajaran lain.

\section{Kajian Produk Akhir}

Pengembangan CAI (computer assisted instructional media) atau media pembelajaran berbantuan komputer untuk menanamkan kesadaran lingkungan bagi siswa SMP sudah melalui beberapa tahap. Tahapan tersebut meliputi uji coba one-to-one evaluation, small group evaluation, serta field trial dan menghasilkan suatu produk akhir. Produk tersebut memiliki karakteristik sebagai berikut. (1) Aspek pembelajaran: kesesuaian materi dengan kompetensi dasar (baik), ketepatan pemilihan materi dengan tujuan pembelajaran (baik), kejelasan petunjuk belajar (baik), kemudahan memilih menu belajar (baik), tingkat interaksi siswa dengan media (baik), ketepatan pemilihan bahasa dalam uraian (baik), pemberian motivasi belajar (baik); (2) Aspek isi: kebenaran konsep (baik), kecukupan materi untuk mencapai tujuan (baik), kejelasan materi (baik), sistematika penyajian materi (baik), urutan materi (baik), kelayakan contoh yang disajikan (baik), kelugasan bahasa (baik), kejelasan bahasa (baik), ketepatan animasi untuk menjelaskan materi (baik), ketepatan gambar untuk menjelaskan materi (baik); (3) Aspek tampilan: kesesuaian pemilihan warna tulisan (baik), ketepatan pemilihan jenis huruf (baik), ketepatan pemilihan ukuran huruf (baik), ketepatan ukuran gambar (baik), ketepatan warna gambar (baik), ketepatan pemilihan warna pada background (baik), keserasian warna tulisan dengan warna background (baik), keserasian warna pada tombol (button) dengan background (baik), ketepatan musik pengiring belajar (baik), komposisi layout setiap slide (baik), tampilan desain pembukaan (baik), kemenarikan animasi pada tulisan (baik), kemenarikan animasi pada gambar (baik), variasi transisi setiap slide (baik), variasi transisi setiap slide (baik), penempatan tombol (button) (baik), konsistensi tombol (button) (baik), ukuran tombol (button) (baik), ketepatan pemilihan warna pada tombol (baik); (4) Aspek pemrograman: tingkat interaksi siswa dengan media (baik), kemudahan berinteraksi dengan media (baik), kejelasan petunjuk penggunaan media (baik), kemudahan penggunaan tombol (baik), kemudahan pemilihan menu (baik), kecepatan animasi (baik), pengaturan animasi (baik), efisiensi penggunaan slide (baik).

\section{Simpulan dan Saran}

Simpulan

Berdasarkan hasil penelitian dan pengembangan, dapat disimpulkan bahwa produk media pembelajaran berbantuan komputer untuk menanamkan kesadaran lingkungan bagi siswa SMP adalah sebagai berikut. (1) Media pembelajaran berbantuan komputer untuk menanamkan kesadaran lingkungan bagi siswa SMP dikembangkan melalui enam langkah, yaitu: (a) identifikasi tujuan pembelajaran, (b) analisis kebutuhan, (c) desain pengembangan, (d) produk awal, (e) evaluasi, (f) produk akhir. (2) Media pembelajaran dinilai layak berdasarkan hasil validasi ahli materi, ahli media, one-to-one evaluation, small group evaluation, dan field trial produk, layak digunakan sebagai media pembelajaran bagi siswa SMP. Hal ini ditunjukkan oleh hasil validasi dari aspek pembelajaran, isi, tampilan dan pemrograman masuk ke kategori baik dan sangat baik. Kategori tersebut telah melampaui batas minimal suatu media pembelajaran dinyatakan layak yaitu cukup. (3) Hasil angket pada field trial menunjukkan bahwa tingkat kesadaran lingkungan siswa tinggi. Namun, ada beberapa bagian aspek yang perlu ditekankan pada saat 
pembelajaran seperti: cara menebang pohon yang baik; pelaksanaan tindakan tanggap bencana; cara mengambil sumber daya; penggunaan lampu led, penggunaan tissue; penggunaan air; penggunaan plastik sehingga media pembelajaran dapat berfungsi secara optimal.

Saran

Berdasarkan kesimpulan yang telah diperoleh dapat dikemukakan saran yang berhubungan dengan pemanfaatan, desiminasi dan pengembangan produk lebih lanjut. (1) Produk media pembelajaran dapat digunakan sebagai sumber belajar secara mandiri, dan jika memungkinkan dapat digunakan secara kelompok atau klasikal. Siswa dapat mempelajari media pembelajaran di sekolah maupun di rumah. (2) Produk media pembelajaran dapat digunakan sebagai alat bantu pembelajaran di SMP. (3) Produk media pembelajaran sebaiknya disebarluaskan ke sekolahsekolah lain melalui pameran pendidikan dan pertemuan Musyawarah Guru Mata Pelajaran (MGMP). (4) Perlu diupayakan pengembangan lebih lanjut dari aspek SK/KD dan tujuan pembelajaran, agar lebih banyak materi yang dapat dikembangkan sebagai sumber belajar mandiri siswa. (5) Pengembangan media pembelajaran selanjutnya lebih kontekstual dan mengikuti perkembangan teknologi agar tetap menarik perhatian dan memberikan motivasi belajar kepada siswa.

\section{Daftar Pustaka}

Alessi, S. M., \& Trollip, S. R. (2001). Multimedia for learning: methods and development (3rd ed). Massacusetts: Allyn \& Bacon.

Ali, Mohammad \& Asrori, Mohammad. (2008). Psikologi remaja. Jakarta: Bumi Aksara.

Arsyad, Azhar. (2009). Media pembelajaran. Jakarta: PT. Raja Grafindo Persada.

Azwar, Saifuddin. (2010). Tes prestasi. Yogyakarta: Pustaka Pelajar.

Borg, W. R, Gall, M. D \& Gall, J. P. (2007). Educational research (8th ed.). New York: Longman.

BSNP. (2006). Standar isi untuk satuan pendidikan dasar dan menengah: standar kompetensi dan kompetensi dasar.
Chee, T.S \& Wong, A. F. L. (2003). Teaching and learning with technology: an Asia-Pasifik perspective. Singapore: Prentice Hall.

Chiras, D. D. (1988). Environmental science: a framework for decision making. New York: Harper-Collis.

Dick, W. \& Carey, L. (2005). The systematic design of instruction. New York: Harper-Collis.

Ellis, A. K. (1998). Teaching and learning elemantary social studies (6th ed.). Needham Heights, United States of Amerika: A Viacom Company.

Munir. (2009). Pembelajaran jarak jauh berbasisteknologi informasi \& komunikasi. Bandung: Alfabeta

Neolaka, Amos. (2008). Kesadaran lingkungan. Jakarta: Rineka Cipta

Newby, T. J, et al. (2000). Instructional technology for teaching and learning: designing instruction. Integrating computers and using media (2nd ed.). New Jersey: Prentice Hall.

Poerwanti, Endang \& Widodo, Nur. (2002). Perkembangan peseta didik. Malang: Univesitas Muhammadiyah Malang.

Sapriya. (2009). Pendidikan IPS: konsep dan pembelajaran. Bandung: Remaja Rosdakarya.

Somantri, Numan. (2001). Menggagas pembaharuan pendidikan IPS. Bandung: PT. Remaja Rosdakarya.

Sudjana, N., \& Rivai, A. (2007). Teknologi pengajaran. Bandung: Sinar Baru Algensindo.

Somantri, Numan. (2001). Menggagas pembaharuan pendidikan IPS. Bandung: PT. Remaja Rosdakarya.

Sukardjo. (2006). Kumpulan materi evaluasi pembelajaran. Prodi Teknologi Pendidikan: PPs UNY.

Yusuf, Syamsu. (2004). Perkembangan anak dan remaja. Bandung: PT Remaja Rosdakarya. 